\title{
Diverse Silver(I) Coordination Chemistry with Cyclic Selenourea Ligands +
}

Justin H. Perras, Stefan M. J. Mezibroski, Matthew A. Wiebe, and Jamie S. Ritch*

*Department of Chemistry, The University of Winnipeg, 515 Portage Avenue, Winnipeg, MB, R3B 2E9, Canada; email: j.ritch@uwinnipeg.ca; phone: +1-204-786-9730; fax: +1-204-774-2401

†Electronic Supplementary Information available: Crystallographic data tables, high-resolution mass spectra, and ${ }^{77}$ Se NMR spectra. CCDC $1583881-1583885$ contain the supplementary crystallographic data (.cif files).

\section{Table of Contents Entry}

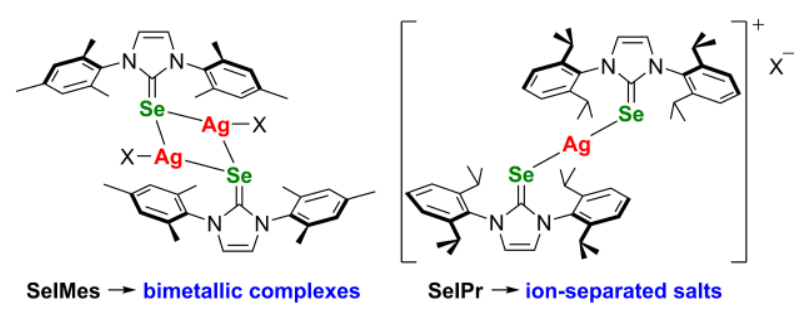

The reactions of cyclic selenoureas with silver(I) salts yield new coordination complexes with stericallycontrolled solid state aggregation. 


\begin{abstract}
The coordination chemistry of two selenourea ligands (SelMes and SeIPr) towards silver(I) triflate and silver(I) nitrate was investigated. Two aggregation modes were observed in the solid state, strongly influenced by the size of the aromatic substituents on the ligand. With mesityl groups, selenium-bridged bimetallic motifs $\left[\mathrm{AgX}(\text { SelMes) }]_{2}\right.$ were obtained, while for the bulkier diisopropylphenyl groups ion-separated species of formulae $\left[\mathrm{Ag}(\mathrm{SeIPr})_{2}\right]^{+}[\mathrm{X}]^{-}$were obtained. Recrystallization of $\left[\mathrm{Ag}\left(\mathrm{NO}_{3}\right)(\text { SelMes })\right]_{2}$ from hot methanol resulted in the formation of a unique coordination polymer featuring three silver environments. Characterization of the complexes by NMR spectroscopy and mass spectrometry suggested all complexes adopt the ionic aggregation mode in methanol solution.
\end{abstract}

\title{
Introduction
}

Organosubstituted selenoureas, $\mathrm{R}_{2} \mathrm{NC}(=\mathrm{Se}) \mathrm{NR}_{2}(\mathrm{R}=$ alkyl, aryl), have been of growing interest in recent years as new aspects of their fundamental chemistry and potential applications are uncovered. Though known for decades prior, these compounds experienced a surge of research attention in the 1990 s as, for instance, precursors to hypervalent selenium centres and diselenide dications, ${ }^{1,2}$ and as electron donors for organic conductive materials. ${ }^{3}$ Cyclic selenoureas are particularly popular, as they can be prepared from imidazolium or imidazolinium precursors to $\mathrm{N}$-heterocyclic carbenes (NHCs), or from the NHCs themselves. Due to the popularity of NHCs, there are various reliable synthetic routes to these precursors, including many known substitution patterns. ${ }^{4}$ 
In more recent years, the coordination chemistry of selenoureas has been explored more extensively, with transition metal complexes being investigated as potential catalysts for organic transformations, ${ }^{5}$ models of biological systems, ${ }^{6,7}$ or as solid-state materials precursors. ${ }^{8,9}$ As selenium is a soft Lewis base, the mid to late transition metals have been a particular focus. Selenoureas derived from NHCs have also been utilized as a probe of the electronic properties of the parent NHC ligands via the ${ }^{77}$ Se chemical shift values. ${ }^{10,11}$

Popular selenourea ligands include $N, N^{\prime}$-dimethylimidazole selone (dmise), and related alkylbridged bis(methylimidazole selone) ligands. Recently more sterically encumbered aryl substituted monodentate selenoureas have gained popularity, including SelMes, featuring 2,4,6-trimethylphenyl (Mes) groups and SelPr which has 2,6-diisopropylphenyl (Dipp) groups (Chart 1). The $\mathrm{C}=\mathrm{Se}$ functional group has also been incorporated into tridentate pincer ${ }^{12,13}$ and scorpionate ${ }^{14}$ ligand platforms.

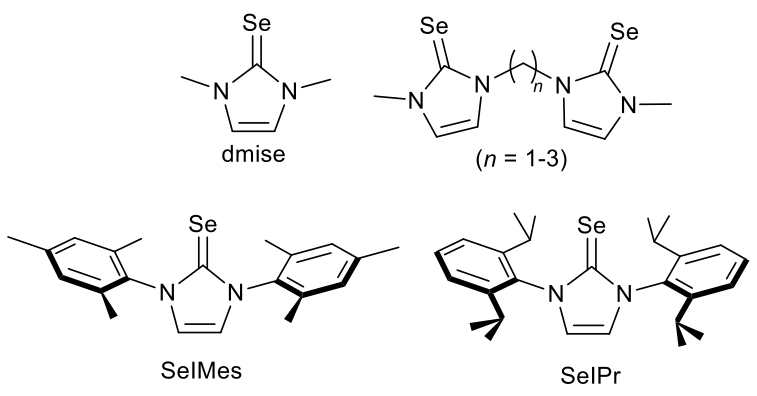

Chart 1.

The coordination chemistry of aryl-substituted selenoureas is not as well-investigated as for the alkyl-substituted variants; only bismuth, ${ }^{15}$ copper, ${ }^{16,17}$ and gold ${ }^{18,19}$ complexes have been 
crystallographically characterized. Given their high chemical stability and ability to control coordination geometry at metal centres, as well as the possibility of providing metal-arene bonding interactions, ${ }^{20}$ aryl substituents have great potential to enable new aspects of selenourea coordination chemistry.

Coinage metal complexes of selenium-bearing ligands have a number of current applications, including usage as emissive materials, ${ }^{21}$ or studying the antioxidant properties of selenium. ${ }^{22-24}$ Copper $^{25}$ and gold ${ }^{18}$ coordination chemistry of selenoureas has been explored quite extensively, but there are notably few studies on silver, ${ }^{26}$ and no silver complexes of aryl-substituted selenoureas have been previously reported. Silver coordination complexes show promise in a number of applications, including as antimicrobial therapeutics, ${ }^{27}$ catalysts ${ }^{28,29}$ or co-catalysts ${ }^{30}$ for a number of organic transformations, and precursors to silver chalcogenide materials. ${ }^{31-33}$ As the silver chemistry of selenoureas is underrepresented, and aryl-substituted selenoureas have the potential to uncover new coordination chemistries, we have pursued this area using SelMes and SelPr to enhance understanding of this class of compounds. In this contribution we present new silver(I) complexes of these ligands, and demonstrate the effect of aryl substitution and counter-ion identity on their structural chemistry.

\section{Experimental}

General Procedures. Unless specified otherwise, all reactions were conducted in ambient conditions using ACS-grade solvents. Reactions vessels and product vials were shielded from light by covering with aluminium foil. No special precautions were taken to exclude air or moisture. The ligands SeIMes and SeIPr were prepared according to the reported procedure for 
SelMes. ${ }^{18}$ Silver(I) triflate and silver(I) nitrate were obtained from commercial sources and used as received.

Instrumentation. NMR spectra were collected on a Bruker $400 \mathrm{MHz}$ Avance III spectrometer. Chemical shifts are reported in parts per million (ppm); J values are given in hertz $(\mathrm{Hz}) .{ }^{1} \mathrm{H}$ and ${ }^{13} \mathrm{C}$ resonances are referenced to residual proton-containing species within the deuterated solvent or the deuterated solvent itself using reported values, ${ }^{34}$ relative to $\mathrm{SiMe}_{4} .{ }^{19} \mathrm{~F}$ and ${ }^{77} \mathrm{Se}$ NMR spectra were referenced externally using $\mathrm{C}_{6} \mathrm{~F}_{6}$ in $\mathrm{CDCl}_{3}(\delta-164.9)$ and $\mathrm{Ph}_{2} \mathrm{Se}_{2}$ in $\mathrm{CDCl}_{3}(\delta$ 463) relative to $\mathrm{CFCl}_{3}$ and $\mathrm{SeMe}_{2}$, respectively. Elemental analyses were performed by Canadian Microanalytical Ltd. (Delta, BC, Canada). High resolution mass spectra (HRMS) were obtained using an orthogonal time-of-flight mass spectrometer with electrospray ionization (ESI) of methanol solutions. Melting points were determined using a Mel-Temp apparatus using samples in sealed capillary tubes.

Synthesis of SelMes and SeIPr. Following the literature procedure, ${ }^{18}$ the products were prepared as pale yellow and colourless crystalline solids, respectively. To our knowledge the ${ }^{1} \mathrm{H}$ NMR data of these compounds have not been reported in deuterated methanol. SelMes: ${ }^{1} \mathrm{H}$ $\operatorname{NMR}\left(\mathrm{CD}_{3} \mathrm{OD}\right): \delta 7.29(\mathrm{~s}, 2 \mathrm{H}, \mathrm{CH}=\mathrm{CH}), 7.04(\mathrm{~s}, 4 \mathrm{H}$, arom. $\mathrm{CH}), 2.35\left(\mathrm{~s}, 6 \mathrm{H}\right.$, arom. $\left.p-\mathrm{CH}_{3}\right), 2.08(\mathrm{~s}$, $12 \mathrm{H}$, arom. $\left.o-\mathrm{CH}_{3}\right)$. SelPr: ${ }^{1} \mathrm{H}$ NMR $\left(\mathrm{CD}_{3} \mathrm{OD}\right): \delta 7.48\left(\mathrm{t},{ }^{3} \mathrm{~J}_{\mathrm{HH}}=7.8 \mathrm{~Hz}, 2 \mathrm{H}\right.$ arom. $\left.p-\mathrm{CH}\right), 7.40(\mathrm{~s}, 2 \mathrm{H}$, $\mathrm{CH}=\mathrm{CH}), 7.33\left(\mathrm{~d}, 3^{3} \mathrm{JH}_{\mathrm{H}}=7.8 \mathrm{~Hz}, 4 \mathrm{H}\right.$, arom. $\left.m-\mathrm{CH}\right), 2.67\left(\right.$ sept, $\left.{ }^{3} \mathrm{~J}_{\mathrm{HH}}=7.0 \mathrm{~Hz}, 4 \mathrm{H}, \mathrm{CH}\left(\mathrm{CH}_{3}\right)_{2}\right), 1.31(\mathrm{~d}$, $\left.{ }^{3} J_{\mathrm{HH}}=7.0 \mathrm{~Hz}, 12 \mathrm{H}, \mathrm{CH}\left(\mathrm{CH}_{3}\right)_{2}\right), 1.20\left(\mathrm{~d},{ }^{3} \mathrm{~J}_{\mathrm{HH}}=7.0 \mathrm{~Hz}, 12 \mathrm{H}, \mathrm{CH}\left(\mathrm{CH}_{3}\right)_{2}\right)$.

General Procedure for Synthesis of Silver Complexes. To a $100 \mathrm{~mL}$ round-bottom flask equipped with a magnetic stir bar was added the ligand, and either acetone or methanol. After 
stirring for several minutes, the silver salt was added and the resulting mixtures stirred for $20 \mathrm{~h}$. After workup as indicated, colourless crystalline solids were obtained.

Synthesis of $\left\{\mathrm{Ag}(\text { SelMes)(OTf) }\}_{2}\right.$ ([1]OTf). The reaction of SelMes $(105.2 \mathrm{mg}, 0.27 \mathrm{mmol})$ and AgOTf $(70 \mathrm{mg}, 0.27 \mathrm{mmol})$ in acetone $(50 \mathrm{~mL})$ resulted in an oily product after removal of the volatiles under vacuum. Trituration with hexanes $(2 \times 5 \mathrm{~mL})$ followed by vacuum drying afforded [1]OTf as a colourless crystalline solid $\left(100.4 \mathrm{mg}, 57 \%\right.$, m.p. $220{ }^{\circ} \mathrm{C}$ (dec. without melting)). ${ }^{1} \mathrm{H} N M R\left(\mathrm{CD}_{3} \mathrm{OD}\right): \delta 7.64(\mathrm{~s}, 2 \mathrm{H}, \mathrm{CH}=\mathrm{CH}), 7.12(\mathrm{~s}, 4 \mathrm{H}$, arom. $\mathrm{CH}), 2.34(\mathrm{~s}, 6 \mathrm{H}$, arom. $p$ $\left.\mathrm{CH}_{3}\right), 2.04\left(\mathrm{~s}, 12 \mathrm{H}\right.$, arom. $\left.\mathrm{o}-\mathrm{CH}_{3}\right) ;{ }^{1} \mathrm{H}$ NMR (acetone- $\left.\mathrm{d}_{6}\right): \delta 7.82(\mathrm{~s}, 2 \mathrm{H}, \mathrm{CH}=\mathrm{CH}), 7.17(\mathrm{~s}, 4 \mathrm{H}$ arom. $\mathrm{CH}), 2.36\left(\mathrm{~s}, 6 \mathrm{H}\right.$, arom. $\left.p-\mathrm{CH}_{3}\right), 2.08\left(\mathrm{~s}, 12 \mathrm{H}\right.$, arom. $\left.o-\mathrm{CH}_{3}\right) ;{ }^{13} \mathrm{C}$ NMR $\left(\mathrm{CD}_{3} \mathrm{OD}\right): \delta 147.7$ (br s), $142.8(\mathrm{~s}), 136.2(\mathrm{~s}), 134.1(\mathrm{~s}), 131.3(\mathrm{~s}), 125.1(\mathrm{~s}), 21.4(\mathrm{~s}), 18.1(\mathrm{~s}) ;{ }^{19} \mathrm{~F}$ NMR (acetone- $\mathrm{d}_{6}$ ): $\delta$ -78.6 (s); ${ }^{19} \mathrm{~F}$ NMR (CD $\left.30 \mathrm{OD}\right): \delta-80.1$ (s). Anal. Calcd (\%) for $\mathrm{C}_{44} \mathrm{H}_{48} \mathrm{~N}_{4} \mathrm{~F}_{6} \mathrm{O}_{6} \mathrm{~S}_{2} \mathrm{Se}_{2} \mathrm{Ag}_{2}$ : C: 41.27; $\mathrm{H}$ : 3.78; N: 4.37; found: C: 41.61; H: 3.91; N: 4.33. HRMS (ESI) $m / 2$ : [M] ${ }^{+}$calcd. for $\mathrm{C}_{42} \mathrm{H}_{48} \mathrm{AgN}_{4} \mathrm{Se}_{2}$ : 875.1255; found: 875.1235. X-ray quality crystals of [1]OTf•2THF were grown from a THF solution of the complex layered with hexanes and stored at $-30^{\circ} \mathrm{C}$.

Synthesis of $\left\{\mathrm{Ag}\left(\text { SelMes) }\left(\mathrm{NO}_{3}\right)\right\}_{2}\left([1] \mathrm{NO}_{3}\right)\right.$. The reaction of SelMes $(114.5 \mathrm{mg}, 0.30 \mathrm{mmol})$ and $\mathrm{AgNO}_{3}(50.3 \mathrm{mg}, 0.30 \mathrm{mmol})$ in methanol $(50 \mathrm{~mL})$ yielded [1] $\mathrm{NO}_{3}$ as a colourless crystalline solid after removal of the volatiles under vacuum $\left(104.3 \mathrm{mg}, 63 \%\right.$, m.p. $240{ }^{\circ} \mathrm{C}$ (dec. without melting)). ${ }^{1} \mathrm{H} N M R\left(\mathrm{CD}_{3} \mathrm{OD}\right): \delta 7.68(\mathrm{~s}, 2 \mathrm{H}, \mathrm{CH}=\mathrm{CH}), 7.12(\mathrm{~s}, 4 \mathrm{H}$, arom. $\mathrm{C}-\mathrm{H}), 2.35\left(\mathrm{~s}, 6 \mathrm{H}, p-\mathrm{CH}_{3}\right)$, $2.04\left(\mathrm{~s}, 12 \mathrm{H}, \mathrm{o}-\mathrm{CH}_{3}\right) ;{ }^{13} \mathrm{C}\left\{{ }^{1} \mathrm{H}\right\}$ NMR (CD $\left.3 \mathrm{OD}\right): \delta 147.2$ (br s), $142.8(\mathrm{~s}), 136.3$ (s), 134.1 (s), 131.3 (s), $125.1(\mathrm{~s}), 21.4(\mathrm{~s}), 18.1$ (s). Anal. Calcd (\%) for $\mathrm{C}_{42} \mathrm{H}_{48} \mathrm{~N}_{6} \mathrm{O}_{6} \mathrm{Se}_{2} \mathrm{Ag}_{2}: \mathrm{C}: 45.59 ; \mathrm{H}: 4.37 ; \mathrm{N}: 7.60$; found: C: 44.63; H: 4.23; N: 7.50. HRMS (ESI) m/z: [M] $]^{+}$calcd. for $\mathrm{C}_{42} \mathrm{H}_{48} \mathrm{AgN}_{4} \mathrm{Se}_{2}$ : 875.1255; 
found: 875.1240 . X-ray quality crystals of $[1] \mathrm{NO}_{3}$ were grown by slow evaporation of a methanol solution of the complex.

Formation of $\left[\mathrm{Ag}_{3}\left(\mathrm{NO}_{3}\right)_{3}(\mathrm{SelMes})_{2}\right] \bullet \mathrm{MeOH}$ (3). A sample of $[1] \mathrm{NO}_{3}$ was dissolved in boiling methanol and allowed to slowly cool to room temperature. A large colourless $\mathrm{X}$-ray quality crystal of complex $\mathbf{3}$ formed over a period of days.

Synthesis of $\left[\mathrm{Ag}(\mathrm{SelPr})_{2}\right][\mathrm{OTf}]$ ([2]OTf). The reaction of SelPr (108.8 mg, $\left.0.23 \mathrm{mmol}\right)$ and AgOTf $(29 \mathrm{mg}, 0.11 \mathrm{mmol})$ in acetone $(50 \mathrm{~mL})$ afforded the product as a colourless crystalline solid after drying under vacuum (98.4 mg, $71 \%$, m.p. $>250{ }^{\circ} \mathrm{C}$ ). ${ }^{1} \mathrm{H}$ NMR (acetone- $\mathrm{d}_{6}$ ): $\delta 7.88(\mathrm{~s}$, $2 \mathrm{H}, \mathrm{CH}=\mathrm{CH}), 7.51\left(\mathrm{t},{ }^{3} \mathrm{~J}_{\mathrm{HH}}=7.8 \mathrm{~Hz}, 2 \mathrm{H}\right.$, arom. $\left.p-\mathrm{CH}\right), 7.38\left(\mathrm{~d},{ }^{3} \mathrm{JHH}_{\mathrm{HH}}=7.8 \mathrm{~Hz}, 4 \mathrm{H}\right.$, arom. $\left.m-\mathrm{CH}\right), 2.46$ (sept, $\left.{ }^{3} \mathrm{~J}_{\mathrm{HH}}=6.8 \mathrm{~Hz}, 4 \mathrm{H}, \mathrm{CH}\left(\mathrm{CH}_{3}\right)_{2}\right), 1.30\left(\mathrm{~d},{ }^{3} \mathrm{~J}_{\mathrm{HH}}=6.8 \mathrm{~Hz}, 12 \mathrm{H}, \mathrm{CH}\left(\mathrm{CH}_{3}\right)_{2}\right), 1.15\left(\mathrm{~d},{ }^{3} \mathrm{~J}_{\mathrm{HH}}=6.8 \mathrm{~Hz}\right.$, $\left.12 \mathrm{H}, \mathrm{CH}\left(\mathrm{CH}_{3}\right)_{2}\right) ;{ }^{1} \mathrm{H}\left(\mathrm{CD}_{3} \mathrm{OD}\right): \delta 7.70(\mathrm{~s}, 2 \mathrm{H}, \mathrm{CH}=\mathrm{CH}), 7.48\left(\mathrm{t},{ }^{3} \mathrm{~J}_{\mathrm{HH}}=7.8 \mathrm{~Hz}, 2 \mathrm{H}\right.$, arom. $\left.p-\mathrm{CH}\right), 7.34$ (d, ${ }^{3} \int_{\mathrm{HH}}=7.8 \mathrm{~Hz}, 4 \mathrm{H}$, arom. $\left.m-\mathrm{CH}\right), 2.40\left(\right.$ sept, $\left.{ }^{3} \mathrm{JHH}_{\mathrm{H}}=6.9 \mathrm{~Hz}, 4 \mathrm{H}, \mathrm{CH}\left(\mathrm{CH}_{3}\right)_{2}\right), 1.28\left(\mathrm{~d},{ }^{3} /_{\mathrm{HH}}=6.9 \mathrm{~Hz}\right.$, $\left.12 \mathrm{H}, \mathrm{CH}\left(\mathrm{CH}_{3}\right)_{2}\right), 1.16\left(\mathrm{~d},{ }^{3} \jmath_{\mathrm{HH}}=6.9 \mathrm{~Hz}, 12 \mathrm{H}, \mathrm{CH}\left(\mathrm{CH}_{3}\right)_{2}\right) ;{ }^{13} \mathrm{C}\left\{{ }^{1} \mathrm{H}\right\} \mathrm{NMR}\left(\mathrm{CD}_{3} \mathrm{OD}\right): \delta 154.9(\mathrm{~s}), 147.0$ (s), $134.2(\mathrm{~s}), 132.6(\mathrm{~s}), 126.2(\mathrm{~s}), 125.4(\mathrm{~s}), 30.3(\mathrm{~s}), 24.5(\mathrm{~s}), 24.0(\mathrm{~s}) .{ }^{19} \mathrm{~F}\left\{{ }^{1} \mathrm{H}\right\}$ NMR (acetone- $\left.\mathrm{d}_{6}\right)$ : $\delta-79.8(\mathrm{~s}) ;{ }^{19} \mathrm{~F}\left\{{ }^{1} \mathrm{H}\right\}$ NMR $\left(\mathrm{CD}_{3} \mathrm{OD}\right): \delta-80.2(\mathrm{~s}) ;{ }^{77} \mathrm{Se}\left\{{ }^{1} \mathrm{H}\right\}$ NMR $\left(\mathrm{CD}_{3} \mathrm{OD}\right): \delta-9.4$ (overlapping $\mathrm{d}$, ${ }^{1} 1_{109 \mathrm{AgSe}}=126 \mathrm{~Hz},{ }^{1} J_{107 \mathrm{AgSe}}=114 \mathrm{~Hz}$ ). Anal. Calcd (\%) for $\mathrm{C}_{55} \mathrm{H}_{72} \mathrm{~N}_{4} \mathrm{~F}_{3} \mathrm{O}_{3} \mathrm{SSe}_{2} \mathrm{Ag}: \mathrm{C}: 55.42 ; \mathrm{H}: 6.09$; $\mathrm{N}: 4.70$; found: C: $54.98 ; \mathrm{H}: 6.24 ; \mathrm{N}$ : 4.45. HRMS (ESI) $\mathrm{m} / \mathrm{z}$ : $[\mathrm{M}]^{+}$calcd. for $\mathrm{C}_{54} \mathrm{H}_{72} \mathrm{AgN}_{4} \mathrm{Se}_{2}$ : 1043.3133; found: 1043.3154. X-ray quality crystals of [2]OTf•THF were grown from a THF solution of the complex layered with hexanes and stored at $-30^{\circ} \mathrm{C}$.

Synthesis of $\left[\mathrm{Ag}(\mathrm{SelPr})_{2}\right]\left[\mathrm{Ag}\left(\mathrm{NO}_{3}\right)_{2}\right]\left([2]\left[\mathrm{Ag}\left(\mathrm{NO}_{3}\right)_{2}\right]\right)$. The reaction of SelPr $(104.1 \mathrm{mg}, 0.22$ mmol) and $\mathrm{AgNO}_{3}(37.3 \mathrm{mg}, 0.22 \mathrm{mmol})$ in methanol $(50 \mathrm{~mL})$ yielded a sticky solid that was triturated with hexanes $(2 \times 5 \mathrm{~mL})$. Upon vacuum drying, the product was obtained as a 
colourless crystalline solid ( $103.3 \mathrm{mg}, 73 \%$, m.p. $190{ }^{\circ} \mathrm{C}$ (dec. without melting)). Microanalysis of this product was consistently low in carbon; a sample recrystallized from toluene was analytically pure. ${ }^{1} \mathrm{H}$ NMR (CD $\left.30 \mathrm{OD}\right): \delta 7.73(\mathrm{~s}, 2 \mathrm{H}, \mathrm{CH}=\mathrm{CH}), 7.50\left(\mathrm{t},{ }^{3}{ }_{\mathrm{HH}}=7.8 \mathrm{~Hz}, 2 \mathrm{H}\right.$, arom. o-CH), $7.36\left(\mathrm{~d},{ }^{3} \mathrm{~J}_{\mathrm{HH}}=7.8 \mathrm{~Hz}, 4 \mathrm{H}\right.$, arom. m-CH), $2.41\left(\mathrm{sept},{ }^{3} \mathrm{JHH}_{\mathrm{HH}}=6.8 \mathrm{~Hz}, 4 \mathrm{H}, \mathrm{CH}\left(\mathrm{CH}_{3}\right)_{2}\right), 1.29\left(\mathrm{~d},{ }^{3} \mathrm{~J}_{\mathrm{HH}}=6.8\right.$ $\left.\mathrm{Hz}, 12 \mathrm{H}, \mathrm{CH}\left(\mathrm{CH}_{3}\right)_{2}\right), 1.17\left(\mathrm{~d},{ }^{3} \mathrm{JHH}_{\mathrm{H}}=6.8 \mathrm{~Hz}, 12 \mathrm{H}, \mathrm{CH}\left(\mathrm{CH}_{3}\right)_{2}\right) .{ }^{13} \mathrm{C}\left\{{ }^{1} \mathrm{H}\right\} \mathrm{NMR}\left(\mathrm{CD}_{3} \mathrm{OD}\right): \delta 151.8(\mathrm{~s})$, 146.9 (s), 133.9 (s), 132.8 (s), 126.4 (s), 126.1 (s), 30.4 (s), 24.6 (s), 24.0 (s). ${ }^{77} \mathrm{Se}\left\{{ }^{1} \mathrm{H}\right\}$ NMR (CD $\left.{ }_{3} \mathrm{OD}\right): \delta-68.7$ (br s). Anal. Calcd (\%) for $\mathrm{C}_{54} \mathrm{H}_{72} \mathrm{~N}_{6} \mathrm{O}_{6} \mathrm{Se}_{2} \mathrm{Ag}_{2} \bullet \mathrm{C}_{7} \mathrm{H}_{8}: \mathrm{C}: 53.59 ; \mathrm{H}: 5.90 ; \mathrm{N}: 6.15$; found: C: 53.58; $\mathrm{H}: 5.96$; $\mathrm{N}$ : 6.24. HRMS (ESI) $\mathrm{m} / \mathrm{z}$ : [M] ${ }^{+}$calcd. for $\mathrm{C}_{54} \mathrm{H}_{72} \mathrm{AgN}_{4} \mathrm{Se}_{2}$ : 1043.3133; found: 1043.3137. X-ray quality crystals of $[2]\left[\mathrm{Ag}\left(\mathrm{NO}_{3}\right)_{2}\right] \cdot \mathrm{C}_{7} \mathrm{H}_{8}$ were grown by slow cooling of a solution of the complex in hot toluene.

X-ray Crystallography. A selected crystal of each compound was coated in oil and mounted on a polymer loop. Data were collected on a Bruker D8 Advance ECO X-ray diffractometer with Mok $\alpha$ radiation $(\lambda=0.71073 \AA)$ using $\phi$ and $\omega$ scans. Unit cells were determined from the full data set. Absorption corrections were applied either numerically via face-indexing or with multi-scan methods. Using Olex $2,{ }^{35}$ solutions were obtained by the intrinsic phasing method with the SHELXT program, ${ }^{36}$ and all least-squares refinements were carried out against $F^{2}$ using SHELXL. ${ }^{37}$ Non-hydrogen atoms were modeled anisotropically; hydrogen atoms were treated isotropically and placed in calculated positions using a riding model, unless otherwise specified. Crystal data are presented in Table S1 (Electronic Supplementary Information).

[1]OTf•2THF: A disordered lattice THF molecule was modeled as an anisotropic mixture over two positions using free variable refinement for the occupancy factors of each component 
(63:37). Bond length restraints were applied to the $\mathrm{C}-\mathrm{C}$ and $\mathrm{C}-\mathrm{O}$ distances within the THF molecules.

[2]OTf•THF: The triflate anion features positional disorder over a 2-fold rotation axis. A disordered THF molecule was present, but no suitable refinement model could be found. The electron density associated with this fragment was removed from the reflection data using the SQUEEZE feature of PLATON. ${ }^{38}$

$[2]\left[\mathrm{Ag}\left(\mathrm{NO}_{3}\right)_{2}\right] \bullet \mathrm{C}_{7} \mathrm{H}_{8}:$ A lattice toluene molecule was heavily disordered; no suitable model could be found. The electron density associated with this fragment was removed from the reflection data using the SQUEEZE feature of PLATON. ${ }^{38}$

3: The structure was found to be a two component non-merohedral twin, defined by the twin law [ $\left[\begin{array}{lllllllll}-1 & 0 & 0 & 0 & 1 & 0 & 0 & 0 & -1\end{array}\right]$ with a BASF parameter of $0.299(6)$ and a Flack parameter of $0.0004(15)$

\section{Results and Discussion}

Synthesis. The syntheses of complexes of the selenourea ligands SelMes and SeIPr with AgOTf and $\mathrm{AgNO}_{3}$ were conducted by performing the reactions of equimolar amounts of ligand and metal salt, in acetone or methanol under ambient conditions. After workup, colourless crystalline solids were obtained cleanly in moderate yields (59-73\%) with one exception: the 1:1 combination of SeIPr and AgOTf initially yielded an oily mixture of products from which the product was obtained in $40 \%$ yield after washing with hexanes. Upon recrystallization, the X-ray structure of the product (vide infra) revealed a 2:1 ratio of ligand:metal, thus explaining the low 
yield for the reaction. Repetition of the experiment in the correct 2:1 SelPr:AgOTf stoichiometry afforded product in $71 \%$ yield. The synthetic chemistry is summarized in Scheme 1.

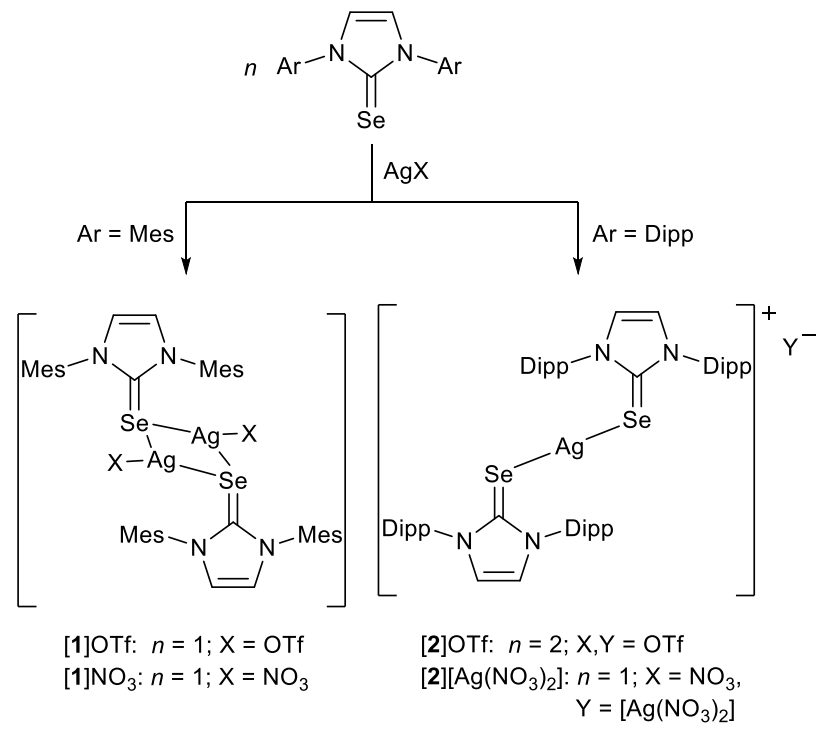

Scheme 1. Synthesis of silver(I) complexes of type $\mathbf{1}$ and $\mathbf{2}$.

The solids did not melt below $250{ }^{\circ} \mathrm{C}$, instead darkening in colour at temperatures ranging from $190-240{ }^{\circ} \mathrm{C}$ (except [2]OTf, which did not change in appearance when heated to $250^{\circ} \mathrm{C}$ ). Dipp-substituted complexes were more soluble than Mes-substituted ones; [2]OTf and [2] $\left[\mathrm{Ag}\left(\mathrm{NO}_{3}\right)_{2}\right]$ were soluble in $\mathrm{CHCl}_{3}$ at room temperature while [1]OTf and [1]NO ${ }_{3}$ required hot $\mathrm{CHCl}_{3}$ to dissolve. All of the complexes were soluble in methanol and, with the exception of [1] $\mathrm{NO}_{3}$, acetone. When recrystallization of [1] $\mathrm{NO}_{3}$ was attempted from hot methanol, a new coordination polymer, 3, was obtained and identified by X-ray diffraction (vide infra). The solid silver(I) complexes appear to be stable to ambient light over the course of several days, however prolonged exposure of several months led to darkening of the samples to brown or grey. We thus recommend long-term storage in amberized or foil-covered vials. Protection of 
solutions and NMR samples with foil is also recommended as the photosensitivity of the samples seems to be higher in the solution state. No particular sensitivity to water or air was noted in either the solid state or in solution, under ambient conditions.

X-Ray Crystallography. At the time of writing, only two silver(I) complexes of selenourea ligands have been characterized crystallographically: a bimetallic complex of unsubstituted selenourea, $\left[\mathrm{Ag}_{2}\left(\mathrm{SeC}\left(\mathrm{NH}_{2}\right)_{2}\right)_{6}\right][\mathrm{Cl}]_{2} \bullet 4\left(\mathrm{HC}(\mathrm{O}) \mathrm{NMe}_{2}\right)_{1}{ }^{39}$ and a tetrametallic cluster, $\left[\mathrm{Ag}_{4}\left(\mathrm{PPh}_{3}\right)_{4}(\mathrm{~L})_{3}\right][\mathrm{OTf}]_{3} \bullet 3\left(\mathrm{OCMe}_{2}\right) \cdot 2\left(\mathrm{H}_{2} \mathrm{O}\right)$, where $\mathrm{L}=$ bis(methylimidazole selone)methane. ${ }^{26}$ Fortunately, the four silver(I) complexes of type $\mathbf{1}$ and $\mathbf{2}$ were readily recrystallized, affording Xray quality single crystals which were analyzed by diffraction. Two distinct structural motifs in the solid state were evident: molecular dimers $\{\operatorname{LAgX}\}_{2}$, and ion-separated salts $\left[\mathrm{L}_{2} \mathrm{Ag}\right]^{+}[\mathrm{X}]^{-}$. The SelMes complexes were dimeric in nature, consisting of two silver(I) centres bridged by two $\mu_{2^{-}}$ Se atoms, and with coordination of the anion ([1]OTf: $\mathrm{CF}_{3} \mathrm{SO}_{3}-\kappa^{1}-\mathrm{O}$, Figure 1 ; [1] $\mathrm{NO}_{3}$ : $\mathrm{NO}_{3}-\kappa^{2}-$ $\mathrm{O} / \mathrm{NO}_{3}-\kappa^{1}-\mathrm{O}$, Figure 2 ). The triflate complex is centrosymmetric, whereas the nitrate complex is asymmetric, as evidenced by the differing binding modes of the nitrate anions - the $\kappa^{2}-\mathrm{O}$ nitrate is perpendicular to the $\mathrm{Ag}_{2} \mathrm{Se}_{2}$ plane and $\kappa^{1}-\mathrm{O}$ nitrate is roughly parallel, but with one oxygen atom close to silver and one further away by ca. $0.5 \AA$. One aromatic "arm" of each selenourea ligand is situated on either side of the $\mathrm{Ag}_{2} \mathrm{Se}_{2}$ planes, which are twisted relative to the mesityl groups at angles ranging from $c a .9-17^{\circ}$ so that each silver atom is closer to one of the aromatic rings.

The shortest silver to arene plane distances (ca. 2.81-2.96 $\AA$ ) are too long to be considered as $\mathrm{Ag}^{+}-\pi$ bonding interactions by the normal criterion $(2.41 \pm 0.05 \AA) .{ }^{40}$ The silver-silver distances 
of $2.7812(7) \AA$ ([1]OTf) and 2.9789(5) $\AA$ ([1] $\left.\mathrm{NO}_{3}\right)$ are significantly shorter than the sum of the van der Waals radii for silver $(3.44 \AA),{ }^{41}$ indicating the possibility of argentophilic interactions. ${ }^{42}$ Such an assignment based only on this distance is tentative in the absence of corroborating spectroscopic and/or computational evidence, particularly since the silver atoms are bridged by the selenium atoms and thus necessarily brought in close proximity.

The planar $\mathrm{Ag}_{2} \mathrm{Se}_{2}$ rings in [1] $\mathrm{NO}_{3}$ and [1]OTf feature similar Ag-Se distances (2.623(1) 2.713(1) $\AA$ ), and internal bond angles (Ag-Se-Ag 62.7(1) - 68.3(1) ; Se-Ag-Se 112.0(1) $\left.117.3(1)^{\circ}\right)$. In turn, these values closely resemble those of a related bimetallic silver complex of selenourea, $\left[\left\{\left(\mathrm{NH}_{2}\right)_{2} \mathrm{CSe}\right\} \mathrm{Ag}\left\{\mu_{2}-\mathrm{SeC}\left(\mathrm{NH}_{2}\right)_{2}\right\}\right]_{2}{ }^{2+}(\mathrm{d}(\mathrm{Ag}-\mathrm{Se})=2.706(1)-2.750(1) \AA \AA \mathrm{Ag}-\mathrm{Se}-\mathrm{Ag}$ 65.69(4) ${ }^{\circ}$; Se-Ag-Se 114.31(4))..$^{39}$

The $\mathrm{Ag}-\mathrm{O}$ distance for the coordinated triflate anion in [1]OTf is 2.303(3) $\AA$, whereas for the nitrate groups in $[1] \mathrm{NO}_{3}$ they range from $2.289(4)-2.578(4) \AA$ for close contacts (from the $\kappa^{2}-\mathrm{O}$ nitrate ligand and the closer oxygen atom from the $\kappa^{1}-\mathrm{O}$ nitrate ligand) to $>2.75 \AA$ for the longer $\mathrm{Ag} \cdots \mathrm{O}$ distance from the $\kappa^{1}-\mathrm{O}$ nitrate ligand.

This bimetallic molecular (neutral) coordination motif is rare for selenoureas. Related analogues include the palladium complex $\left[\left(\mu_{2}-\mathrm{L}\right) \mathrm{PdCl}_{2}\right]$ ( $\mathrm{L}=1$-butyl-3-methylimidazole-2selone $),{ }^{43}$ and the thallium complex $\left[\left(\mu_{2}-\mathrm{L}\right) \mathrm{TI}\right]_{2}\left(\mathrm{~L}=N, N\right.$-diethyl- $N^{\prime}$-benzoylselenoureato $),{ }^{44}$ both of which have been crystallographically characterized. The only similar coinage metal analogues are several dicationic copper(I) complexes of dmise and bis(methylimidazole selone)methane..$^{45}$ Thus, the complexes [1] $\mathrm{NO}_{3}$ and [1]OTf represent the first crystallographically characterized selenourea-group 11 complexes of this type. 


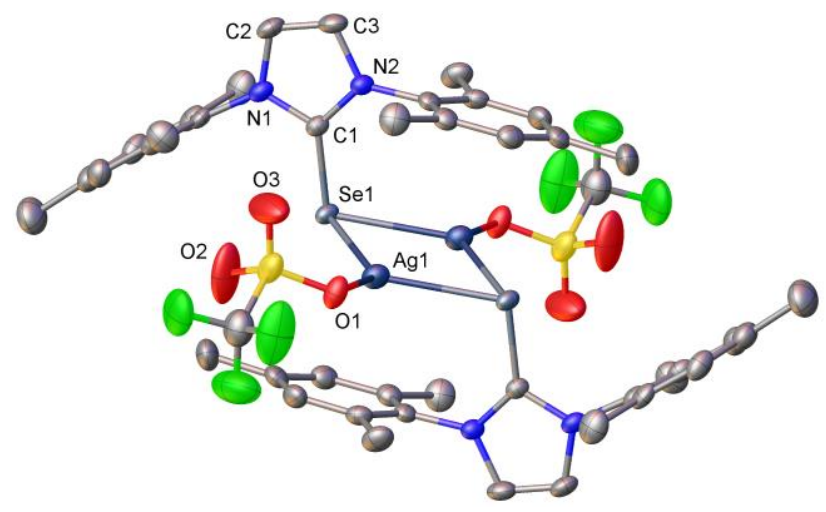

Figure 1. Thermal ellipsoid plot of [1]OTf•2THF (50\% probability level). Hydrogen atoms and the disordered lattice THF molecule are omitted for clarity. Symmetry-equivalent atoms are generated by a crystallographic inversion centre.

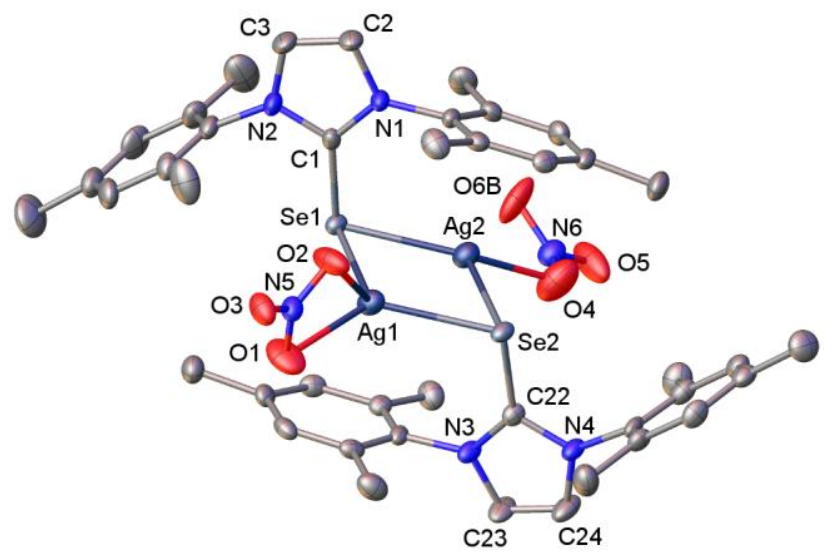

Figure 2. Thermal ellipsoid plot of [1] $\mathrm{NO}_{3}$ (50\% probability level). Hydrogen atoms are omitted for clarity. The atom $\mathrm{O} 6$ is disordered over two positions; one is shown.

By contrast, the SeIPr ligand yielded ion-separated salts with $C_{i}$-symmetric two-coordinate silver(I) cations (Figure 3 is shown as representative of both structures) and either an 
uncoordinated triflate anion, or a $C_{2}$-symmetric $\left[\mathrm{Ag}\left(\mathrm{NO}_{3}\right)_{2}\right]^{-}$complex anion featuring two $\kappa^{2}-\mathrm{O}$ nitrate ions coordinated to another silver(I) centre. The two nitrate groups are not coplanar, but rather rotated by $c a .36^{\circ}$ from one another. The dinitratoargentate(I) ion, featuring two $\left(\mathrm{NO}_{3}-\kappa^{2}-\mathrm{O}\right)$ moieties, is quite rare, appearing in only two previous reports. ${ }^{46,47}$ The twist angles between the two $\mathrm{NO}_{3}$ planes in these structures are 0 and $97^{\circ}$, illustrating the flexible coordination geometry of silver(I) under the influence of different counterions and packing forces. The Ag-Se distances in the cationic complexes are in the range $2.4658(4)-2.4750(2) \AA$, significantly shorter than in the neutral dimeric complexes, as would be expected given the positive charge and the lack of bridging interactions.

A similar interplay between monomeric and dimeric complexes featuring SelMes and SelPr was recently reported in a study on bismuth(III) halide complexes of these ligands. Prabusankar and coworkers have crystallographically characterized the formation of monometallic $\left[\mathrm{BiBr}_{3}(\mathrm{SelPr})\right] \bullet \mathrm{CH}_{2} \mathrm{Cl}_{2}$ for the larger diisopropylphenyl groups, while bimetallic $\left[\left\{\mathrm{BiCl}_{2}\left(\mu_{2^{-}}\right.\right.\right.$ $\left.\mathrm{Cl})(\text { SelMes) }\}_{2}\right] \bullet 4\left(\mathrm{CH}_{2} \mathrm{Cl}_{2}\right)$ is observed for the smaller mesityl substituents. ${ }^{15}$ In the case of the latter complex, two chlorine atoms rather than selenium atoms are involved in the bridge between bismuth(III) centres. Nonetheless, our studies confirm the ability to influence aggregation states of metal centres by subtly varying the steric demands of the supporting selenourea ligands. 


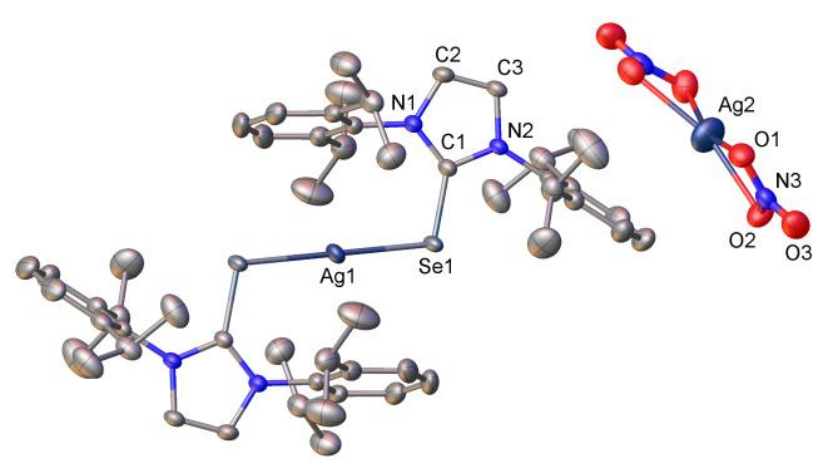

Figure 3. Thermal ellipsoid plot of $[2]\left[\mathrm{Ag}\left(\mathrm{NO}_{3}\right)_{2}\right] \bullet \mathrm{C}_{7} \mathrm{H}_{8}(50 \%$ probability level). Hydrogen atoms are omitted for clarity. Symmetry-equivalent atoms are generated by a crystallographic inversion centre for the cation and a two-fold axis for the anion.

The linear $\left[\mathrm{L}_{2} \mathrm{M}\right]^{+}$bonding motif has been previously observed for both $\operatorname{copper}^{16}$ and gold ${ }^{18}$ in combination with aryl-substituted selenourea ligands. A bent zinc bis(selone) complex has also been reported. ${ }^{48}$ Complexes [2]OTf and [2][Ag( $\left.\left(\mathrm{NO}_{3}\right)_{2}\right]$ represent the first crystallographically characterized silver-selenourea complexes of this type.

The unexpected coordination polymer 3, isolated after an attempted recrystallization of $[1] \mathrm{NO}_{3}$ from boiling methanol, features two $\mu_{2}$-bridging SelMes ligands and three crystallographically unique silver(I) centres, each with different coordination environments (Figure 4). The central six-membered $\mathrm{Ag}_{3} \mathrm{Se}_{2} \mathrm{O}$ ring appears to be unique, with no other such arrangements found in the Cambridge Structural Database. The Ag-Se distances (2.5080(5) 2.5434(6) $\AA$ ) are intermediate between the neutral type 1 and cationic type 2 complexes. Ag1 is two-coordinate, with a close-to-linear geometry (Se-Ag-Se 167.92(2) $)$. Ag2 and Ag3 are each tetracoordinate, featuring one $\mathrm{Ag}-\mathrm{Se}$ interaction and two nitrate ligands: one $\kappa^{2}-\mathrm{O}$ and one $\kappa^{1}$ - 
O. Of the three nitrate anions, one is hydrogen bonded to a lattice methanol molecule, and one is involved in an interaction with the $\mathrm{Ag} 1$ centre of an adjacent cluster. The $\mathrm{Ag} \cdots \mathrm{O}$ distance for this interaction (ca. $2.87 \AA$ ) is significantly longer than the other $\mathrm{Ag}-\mathrm{O}$ contacts in this structure $(2.373(4)-2.511(4) \AA ̊)$ but much shorter than the sum of the van der Waals radii (3.24 Å). Given the interatomic distance and the perturbation of $\mathrm{Ag} 1$ from linear coordination, we ascribe this to a weak contact. Taking this interaction into consideration, the overall packing of structure $\mathbf{3}$ can be described as a coordination polymer with trimetallic repeat units as depicted in Figure 5 .



Figure 4. Thermal ellipsoid plot of $\left[\mathrm{Ag}_{3}\left(\mathrm{NO}_{3}\right)_{3}(\mathrm{SelMes})_{2}\right] \bullet \mathrm{MeOH}(50 \%$ probability level). Carbonbound hydrogen atoms are omitted for clarity.

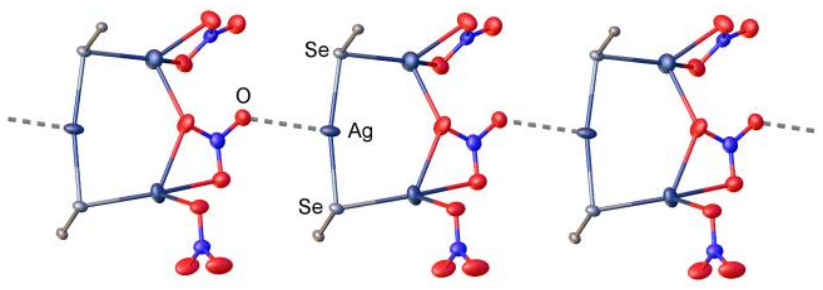


Figure 5. Partial packing diagram for $\left[\mathrm{Ag}_{3}\left(\mathrm{NO}_{3}\right)_{3}(\mathrm{SeIMes})_{2}\right] \bullet \mathrm{MeOH}(50 \%$ probability level) showing 1-dimensional chains. Methanol molecules omitted and only the $\mathrm{C}=\mathrm{Se}$ atoms of selenourea ligands are shown for clarity.

Overall, the structural chemistry of complexes $\mathbf{1}$ and $\mathbf{2}$ presents two aggregation modes, controlled not by the identity of the anion but by the steric demands of the aromatic substitutents on the selenourea ligands. The neutral bimetallic aggregation mode has not been previously observed for the coinage metals. Interestingly, Nolan and coworkers observed two aggregation modes for gold(I) chloride complexes of cyclic selenoureas, but they were monomeric, $[\mathrm{LAuCl}]$, and ionic, $\left[\mathrm{L}_{2} \mathrm{Au}\right]^{+}\left[\mathrm{AuCl}_{2}\right]^{-}$, rather than dimeric and ionic as we have observed for silver(I). ${ }^{18}$ Also of note is that both SelMes and SelPr yielded monomeric structures in the case of gold(I), while the more $\pi$-accepting $\mathrm{Se}(\mathrm{SIMes})$, which features a $\mathrm{CH}_{2} \mathrm{CH}_{2}$ backbone instead of an unsaturated $\mathrm{CH}=\mathrm{CH}$ group, formed the ionic structure.

NMR Spectroscopy. The NMR spectra of complexes 1 and $\mathbf{2}$ were recorded in $\mathrm{CD}_{3} \mathrm{OD}$ to probe their solution structures. Comparing the ${ }^{1} \mathrm{H}$ spectra of the ligands SelMes and SelPr to their silver(I) complexes, the most noticeable change in chemical shift was for the imidazole $\mathrm{CH}$ proton resonance, which becomes deshielded by ca. $+0.37 \mathrm{ppm}$ (SelMes) and +0.23 (SelPr) upon coordination. The NMR spectra for complexes of the same selenourea ligand but different anion are nearly indistinguishable, exhibiting variances of $0.04 \mathrm{ppm}$ or less between the same resonances, indicating the pairs of complexes adopt similar solution structures, and with a low influence, if any, of the anion on the chemical shift values. 
In all cases, the ${ }^{1} \mathrm{H}$ and ${ }^{13} \mathrm{C}$ NMR spectra showed evidence of a single aromatic environment, whereas the solid-state structures exhibit two inequivalent environments. Thus, the solid-state structures do not appear to persist in methanolic solution and the complexes either adopt a new structural motif, undergo dynamic exchange on the NMR timescale, or possibly both. ${ }^{19} \mathrm{~F}$ NMR spectra of the triflate derivatives [1]OTf and [2]OTf exhibit a single resonance at $c a . \delta-80$, which is consistent with a free triflate ion, i.e. no coordination of the $\mathrm{SO}_{3}$ group to a metal centre.

As with the ${ }^{1} \mathrm{H}$ spectra, the ${ }^{13} \mathrm{C}\left\{{ }^{1} \mathrm{H}\right\}$ spectra of complexes with the same selenourea ligand were nearly identical, with all signals deviating no more than $0.3 \mathrm{ppm}$, with the exception of the $\mathrm{C}=\mathrm{Se}$ carbon atoms. The ${ }^{13} \mathrm{C}$ signals for these sites were identified as broad singlets with the most deshielded chemical shift in the spectra for complexes 1 and $\mathbf{2}$, ranging from $\delta 147.2-$ 154.9 ( $\Delta \delta$ of $0.5 \mathrm{ppm}$ for complexes 1 and $3.1 \mathrm{ppm}$ for complexes 2 ). The larger deviations for these carbon atoms are reflective of their close proximity to the silver centres and are thus more influenced by differences in coordination environment at the metal (i.e. anion and/or chemical exchange effects).

A ${ }^{77} \mathrm{Se}\left\{{ }^{1} \mathrm{H}\right\}$ NMR resonance for [2]OTf was observed at $\delta-9.4$ consisting of two overlapping doublets with similar coupling constants $\left({ }^{1} J_{109 \mathrm{AgSe}}=126 \mathrm{~Hz} ;{ }^{1} J_{107 \mathrm{AgSe}}=114 \mathrm{~Hz}\right)$, consistent with coordination of selenium to one silver centre $\left({ }^{107} \mathrm{Ag}: I=1 / 2,52 \% ;{ }^{109} \mathrm{Ag}: I=1 / 2,48 \%\right)$. This is a large shielding effect compared to free ligand $\operatorname{SeIPr}\left(\delta 87\right.$ in acetone- $\left.\mathrm{d}_{6}\right) \cdot{ }^{18}$ By contrast, the ${ }^{77} \mathrm{Se}\left\{{ }^{1} \mathrm{H}\right\}$ NMR spectrum of a concentrated sample of $[2]\left[\mathrm{Ag}\left(\mathrm{NO}_{3}\right)_{2}\right]$ featured a very broad signal at $\delta$ -68.5 (Electronic Supplementary Information). Successive dilutions caused the resonance to 
shift to higher frequency, but the broadness persisted and no spin-spin coupling was resolved in the concentration range tested. It is possible that ligand exchange between the $\left[\mathrm{Ag}(\operatorname{Sel} \operatorname{Pr})_{2}\right]^{+}$ and $\left[\mathrm{Ag}\left(\mathrm{NO}_{3}\right)_{2}\right]^{-}$ions is responsible for the broad signal and chemical shift difference compared to [2]OTf. We were unfortunately unable to observe ${ }^{77}$ Se resonances for complexes [1]OTf and [1] $\mathrm{NO}_{3}$, presumably due to their lower solubility compared to the diisopropylphenyl-substituted analogues.

Related gold complexes, [(SelMes)AuCl] and [(SelPr)AuCl], also exhibited a shielded ${ }^{77} \mathrm{Se}$ chemical shift when compared to the free ligands in $\mathrm{CDCl}_{3}$ solution $(\delta 69$ and 22.5 , compared to $\delta 90$ and 27, respectively). ${ }^{18}$ Though no comparable data is found for aryl-substituted selenourea complexes of silver, a series of silver(I) triflate complexes of alkyl-substituted bis(selone) ligands, $\left\{\mathrm{Ag}_{2} \mathrm{OTf}_{2}\left(\mathrm{PPh}_{3}\right)_{2}(\mathrm{~L})\right\}_{\mathrm{n}}$ exhibited ${ }^{77}$ Se signals (DMSO- $\left.\mathrm{d}_{6}\right)$ in the range $\delta-48.9$ to -98.6, similar to complexes $2 .{ }^{26}$ In these examples, no silver-selenium coupling was resolved.

Mass Spectrometry. To further probe the structures of the complexes, electrospray ionization mass spectrometry studies of methanol solutions were conducted (Electronic Supplementary Information). In all four cases the dominant ion (in positive ion mode) was identified as the linear two-coordinate complex $\left[\mathrm{L}_{2} \mathrm{Ag}\right]^{+}$, suggesting the solution state structures of the type 1 complexes differ in aggregation mode from their solid-state structures. The spectra for SelPr-substituted [2]OTf and [2][Ag( $\left.\left(\mathbf{N O}_{3}\right)_{2}\right]$ contained no significant amounts of other species. However, the SelMes-substituted complexes [1]OTf and [1] $\mathbf{N O}_{3}$ also exhibited significant amounts of ions with the formulation $[\mathrm{LAg}]^{+}$, a monocoordinate cation. This ion was distinguished from $\left[\mathrm{L}_{2} \mathrm{Ag}_{2}\right]^{2+}$ or other higher charged oligomers by examination of the isotopic distribution. The detection of $[\mathrm{LAg}]^{+}$in solutions of the SelMes complexes, but not in SelPr- 
substituted ones, indicates a lesser preference for the $\left[\mathrm{L}_{2} \mathrm{Ag}\right]^{+}$ion in the SelMes systems, which is consistent with the solid-state structures for complexes 1 containing the alternate $\{\operatorname{LAgX}\}_{2}$ aggregation mode. Under the influence of crystal packing forces, this motif appears to dominate.

It is worth noting that while studying gold(I) chloride complexes of SelMes and SelPr, Nolan and coworkers observed a monomeric structure for [AuCl(SelPr)] in the solid state by X-ray diffraction and in $\mathrm{CDCl}_{3}$ solution by DOSY NMR, while ESI data indicated the presence of the salt $\left[\mathrm{Ag}(\mathrm{SelPr})_{2}\right]^{+}\left[\mathrm{AuCl}_{2}\right]^{-.18}$ However, the ESI data were conducted in a different solvent system $\left(\mathrm{CH}_{2} \mathrm{Cl}_{2} / \mathrm{MeOH}\right)$. In our experiments the NMR and ESI data are from methanol solutions, though it is still possible the ionization process in the mass spectrometer is altering the solution composition for the latter.

\section{Conclusions}

The coordination chemistry of silver(I) with cyclic selenourea ligands has been demonstrated to exhibit structural diversity in the solid state, unique to that of the gold(I) analogues. The solution structures of the complexes are ion-separated in nature for both SelMes and SelPr ligands, whereas in the solid state the smaller mesityl-substituted ligands form bimetallic neutral complexes. When heated, the complex $[1] \mathrm{NO}_{3}$ formed a third aggregation type exhibiting trimetallic clusters forming polymer chains.

Overall, the aryl-substituted selenourea ligands SelMes and SeIPr provide several accessible coordination geometries for silver(I), which are significantly influenced by the steric demands of the aromatic groups. This holds promise for extending the coordination chemistry of 
selenourea ligands to other mid-to-late transition metals, which is currently under investigation by our group.

\section{Conflicts of Interest}

There are no conflicts of interest to declare.

\section{Acknowledgements}

Financial support from NSERC (Canada) via a Discovery Development Grant is gratefully acknowledged. Dr. David Herbert (Department of Chemistry, University of Manitoba) is thanked for access to a single-crystal X-ray diffractometer. Mr. Xiao Feng (Maritime Mass Spectrometry Laboratories) is thanked for ESI-MS analyses. 


\section{References}

1 F. Bigoli, F. Demartin, P. Deplano, F. A. Devillanova, F. Isaia, V. Lippolis, M. L. Mercuri, M. A. Pellinghelli and E. F. Trogu, Inorg. Chem., 1996, 35, 3194-3201.

2 S. Yadav, S. T. Manjare, H. B. Singh and R. J. Butcher, Dalton Trans., 2016, 45, 12015-12027.

3 F. Bigoli, P. Deplano, F. A. Devillanova, A. Girlando, V. Lippolis, M.-L. Mercuri, M.-A. Pellinghelli and E. F. Trogu, J. Mater. Chem., 1998, 8, 1145-1150.

4 L. Benhamou, E. Chardon, G. Lavigne, S. Bellemin-Laponnaz and V. César, Chem. Rev., 2011, $111,2705-2733$.

5 W.-G. Jia, Y.-B. Huang, Y.-J. Lin and G.-X. Jin, Dalton Trans., 2008, 5612-5620.

6 B. S. Stadelman, M. M. Kimani, C. A. Bayse, C. D. McMillen and J. L. Brumaghim, Dalton Trans. , 2016, 45, 4697-4711.

7 M. M. Kimani, C. A. Bayse and J. L. Brumaghim, Dalton Trans., 2011, 40, 3711-3723.

8 D. J. Williams, K. M. White, D. VanDerveer and A. P. Wilkinson, Inorg. Chem. Commun., $2002,5,124-126$.

9 T. Bai, C. Li, D. Liang, F. Li, D. Jin, Z. Shi and S. Feng, CrystEngComm, 2013, 15, 6483-6490.

10 A. Liske, K. Verlinden, H. Buhl, K. Schaper and C. Ganter, Organometallics, 2013, 32, 52695272.

11 K. Verlinden, H. Buhl, W. Frank and C. Ganter, Eur. J. Inorg. Chem., 2015, 2416-2425.

12 N. Ghavale, S. T. Manjare, H. B. Singh and R. J. Butcher, Dalton Trans., 2015, 44, 1189311900.

13 V. Rani, H. B. Singh and R. J. Butcher, Eur. J. Inorg. Chem., 2017, 3720-3728. 
14 M. Minoura, V. K. Landry, J. G. Melnick, K. Pang, L. Marchiò and G. Parkin, Chem. Commun., 2006, 3990-3992.

15 K. Srinivas, P. Suresh, C. N. Babu, A. Sathyanarayana and G. Prabusankar, RSC Adv., 2015, 5, 15579-15590.

16 K. Srinivas, C. N. Babu and G. Prabusankar, Dalton Trans., 2015, 44, 15636-15644.

17 N. Parvin, S. Pal, S. Khan, S. Das, S. K. Pati and H. W. Roesky, Inorg. Chem., 2017, 56, 17061712.

18 D. J. Nelson, F. Nahra, S. R. Patrick, D. B. Cordes, A. M. Z. Slawin and S. P. Nolan, Organometallics, 2014, 33, 3640-3645.

19 F. Nahra, S. R. Patrick, D. Bello, M. Brill, A. Obled, D. B. Cordes, A. M. Z. Slawin, D. O’Hagan and S. P. Nolan, ChemCatChem, 2015, 7, 240-244.

20 A. J. Veinot, A. D. K. Todd and J. D. Masuda, Angew. Chem. Int. Ed., 2017, 56, 11615-11619.

21 M. Arca, T. Aroz, M. Concepción Gimeno, M. Kulcsar, A. Laguna, T. Lasanta, V. Lippolis, J. M. López-de-Luzuriaga, M. Monge and M. E. Olmos, Eur. J. Inorg. Chem., 2011, 2288-2297.

22 M. M. Kimani, H. C. Wang and J. L. Brumaghim, Dalton Trans., 2012, 41, 5248-5259.

23 M. M. Kimani, C. A. Bayse, B. S. Stadelman and J. L. Brumaghim, Inorg. Chem., 2013, 52, 11685-11687.

24 V. Lippolis, in Organoselenium Compounds in Biology and Medicine, 2017, pp. 122-149.

25 Bradley S. Stadelman and Julia L. Brumaghim, in Biochalcogen Chemistry: The Biological Chemistry of Sulfur, Selenium, and Tellurium, American Chemical Society, 2013, vol. 1152, pp. 33-70. 
26 M. T. Aroz, M. C. Gimeno, M. Kulcsar, A. Laguna and V. Lippolis, Eur. J. Inorg. Chem., 2011, 2884-2894.

27 S. Medici, M. Peana, G. Crisponi, V. M. Nurchi, J. I. Lachowicz, M. Remelli and M. A. Zoroddu, Coord. Chem. Rev., 2016, 327-328, 349-359.

28 V. K.-Y. Lo, A. O.-Y. Chan and C.-M. Che, Org. Biomol. Chem., 2015, 13, 6667-6680.

29 G. Fang and X. Bi, Chem. Soc. Rev., 2015, 44, 8124-8173.

30 D. Wang, R. Cai, S. Sharma, J. Jirak, S. K. Thummanapelli, N. G. Akhmedov, H. Zhang, X. Liu, J. L. Petersen and X. Shi, J. Am. Chem. Soc., 2012, 134, 9012-9019.

31 A. Panneerselvam, C. Q. Nguyen, M. A. Malik, P. O’Brien and J. Raftery, J. Mater. Chem., 2008, 19, 419-427.

32 R. K. Sharma, A. Wadawale, G. Kedarnath, D. Manna, T. K. Ghanty, B. Vishwanadh and V. K. Jain, Dalton Trans., 2014, 43, 6525-6535.

33 G. K. Kole, K. V. Vivekananda, M. Kumar, R. Ganguly, S. Dey and V. K. Jain, CrystEngComm, $2015,17,4367-4376$.

34 G. R. Fulmer, A. J. M. Miller, N. H. Sherden, H. E. Gottlieb, A. Nudelman, B. M. Stoltz, J. E. Bercaw and K. I. Goldberg, Organometallics, 2010, 29, 2176-2179.

35 O. V. Dolomanov, L. J. Bourhis, R. J. Gildea, J. A. K. Howard and H. Puschmann, J. Appl. Crystallogr., 2009, 42, 339-341.

36 G. M. Sheldrick, Acta Crystallogr. Sect. Found. Adv., 2015, 71, 3-8.

37 G. M. Sheldrick, Acta Crystallogr. A, 2008, 64, 112-122.

38 A. L. Spek, Acta Crystallogr. D Biol. Crystallogr., 2009, 65, 148-155.

39 W. Eikens, P. G. Jones, J. Lautner and C. Thöne, Z. Naturforsch B Chem. Sci., 1993, 49, 21-26. 
40 S. V. Lindeman, R. Rathore and J. K. Kochi, Inorg. Chem., 2000, 39, 5707-5716.

41 A. Bondi, J. Phys. Chem., 1964, 68, 441-451.

42 H. Schmidbaur and A. Schier, Angew. Chem. Int. Ed., 2015, 54, 746-784.

43 C. Wang, Y. Tong, Y. Huang, H. Zhang and Y. Yang, RSC Adv., 2015, 5, 63087-63094.

44 W. Bensch and M. Schuster, Z. Für Anorg. Allg. Chem., 1993, 619, 1689-1692.

45 M. M. Kimani, D. Watts, L. A. Graham, D. Rabinovich, G. P. A. Yap and J. L. Brumaghim, Dalton Trans., 2015, 44, 16313-16324.

46 R. D. Gillard, L. R. Hanton and S. H. Mitchell, Polyhedron, 1990, 9, 2127-2133.

47 H.-L. Hsiao, C.-J. Wu, W. Hsu, C.-W. Yeh, M.-Y. Xie, W.-J. Huang and J.-D. Chen, CrystEngComm, 2012, 14, 8143-8152.

48 C. N. Babu, K. Srinivas and G. Prabusankar, Dalton Trans., 2016, 45, 6456-6465. 